\title{
Spectrophotometric Assay of Iron (II) in Pharmaceutical Formulation Using Alizarin Red Sulphonate Reagent
}

\author{
Thabit S. Al-Ghabsha Amal M. Saeed \\ Department of Chemistry / College of Education \\ University of Mosul / Mosul-Iraq
}

\section{Usra I. Al-Neaimy}

College of Veterinary Medicine

University of Mosul / Mosul-Iraq

Received

17 / 01 / 2010
Accepted

05 / 05 / 2010

\section{الخلاصة}

تم تطوير طريقة طيفية سهلة وسريعة وحساسة لتقدير كميات نزرة من الحديد الثنائي في

المحلول المائي ـ تعتمد الطريقة على تفاعل الحديد الثنائي مع كاثف اليزارين احمر السلفونات وتكوين معقد كيليتي بني اللون في المحلول المائي يمنلك اقصى امنصاص عند طول

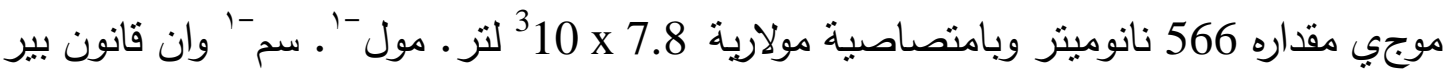

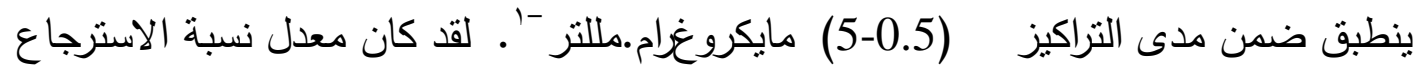

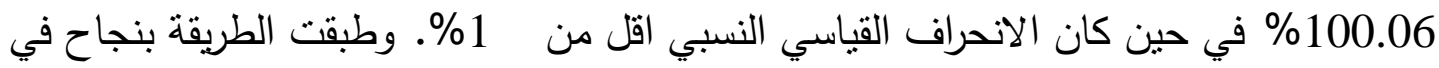
تقدير الحديد في حا لته النقية وفي المستحضرات الصيدلانية (اقراص وكبسولات ) وتم مقارنة النتائج مع الطريقة القياسية المعتمدة في دستور الادوية البريطاني .

\begin{abstract}
A rapid, sensitive and simple spectrophotometric method was developed for the determination of iron (II). The method was based on the reaction of iron (II) with alizarin red sulphonate reagent to form a brown chelating complex in an aqueous solution. The absorbance of the chelating complex was measured at $566 \mathrm{~nm}$ with a molar absorptivity of $7.8 \times 10^{3} 1 . \mathrm{mol}^{-1} . \mathrm{cm}^{-1}$. The chelating complex conforms to Beer's law over the range (0.5-5) $\mu \mathrm{g} \cdot \mathrm{ml}^{-1}$. the average recovery\% was $100.06 \%$ and
\end{abstract}


precision (RSD) was found to be less than 1\%. The method was successfully employed for assay of iron (II) in pharmaceutical formulations (tablets and capsules). The results have been compared with British pharmacopoeia method.

\section{Introduction}

Iron is one of the most important essential elements. Its deficiency or overload may cause health problems. Speciation of iron, occurrence of the element in two oxidation states (II, III) and equilibrium between these forms are important for biological systems using iron for metabolic processes $^{(1)}$.

Spectrophotometric method used for the determination of Iron (II) in pharmaceutical formulations by it's oxidation in the iron (II)/thiocyanate/acetone system at $480 \mathrm{~nm}$ with a molar absorptivity of 2.10x $10^{4} 1 . \mathrm{mol}^{-1} \cdot \mathrm{cm}^{-1(2)}$.

Spectrophotometric method was described for the determination of iron (II) with salicylic and eight mono-substituted salicylic acids in aqueous-acetone solution at $\mathrm{pH}$ range 2-3. Beer's law was followed in the range of (1-60) $\mu \mathrm{g} \cdot \mathrm{ml}^{-1}$. The molar absorptivities of the complexes were 6796 to 473931 . $\mathrm{mol}^{-1} \cdot \mathrm{cm}^{-1(3)}$.

Development of indirect spectrophotometric method for the determination of iron (II) in aqueous solution. The method based on the reaction of iron (III) which produces from the oxidation of iron (II) by hydrogen peroxide) with 3,5-dinitosalicylic acid (DNS) reagent at $\mathrm{pH}$ 2.92 to form orange coloured complex at $475 \mathrm{~nm}$. with a molar absorptivity $75501 . \mathrm{mol}^{-1} \cdot \mathrm{cm}^{-1}$. This method was applied successfully for the assay of $\mathrm{Fe}$ (II) in various pharmaceutical preparations ${ }^{(4)}$.

A spectrophotometric method described for the determination of iron (II) by its oxidation to iron (III) by tetrahydrofuran/water and then reacted with azide reagent to form coloured complex at $396 \mathrm{~nm}^{(5)}$.

Iron (II) has been determined by sequential injection analysis method. The method based on the reaction of iron (II) with 1,10-phenanthroline to form a reddish orange complex which shows maximum absorption at $512 \mathrm{~nm}^{(6)}$.

Spectrophotometric method for determination of iron (II) was described. The method based on the reaction of iron (II) (after reduction of iron (III) with ascorbic acid) with 3-mercapto-5-(2,4dihydroxyphenylazo-1)-1,2,4-triazol (METRIAP) and 5-(5-mercapto1,3,4triadiazolo-2-azo)-2,4-dihydroxybenzoic acid ((METIADAREZ- $\beta$ ) at $\mathrm{pH} 7.4$ to form coloured complexes at $490,600 \mathrm{~nm}$ respectively ${ }^{(7)}$.

The applicability of derivative spectrophotometry for simultaneous determination of zinc(II), manganese(II) and iron(II) in the form of 4-(2pyridyl azo)resorcinol (PAR) complexes was presented and discussed. Beer's law was obeyed in range $0.025-0.2$ for iron ion. The method was 
applied successfully for determination of mentioned ions in pharmaceutical preparation without previous separation ${ }^{(8)}$.

The complexing reagent 2 - thiophenaldehyde -4 - phenyl -3 thiosemicarbazone (TAPT) was examined for high performance liquid chromatographic (HPLC) separations of cobalt(II), copper(II) and iron(II) as metal chelates on a Microsorb C-18, 5- $\mu$ m column UV detection was at $254 \mathrm{~nm}$ with detection limits within $0.5-2.5 \mu \mathrm{g} \cdot \mathrm{ml}^{-1}$ in the final solution. The method was applied for the determination of copper, cobalt and iron in pharmaceutical preparation ${ }^{(9)}$.

The reactions of bis(salicycladehyde)tetramethylethylenediimine $\left(\mathrm{H}_{2} \mathrm{SA}_{2}\right.$ Ten) with cobalt(II), cobalt(III), iron(II) and iron(III) were

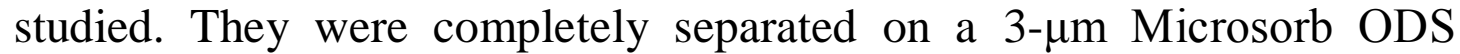
column with spectrophotometric detection at $270 \mathrm{~nm}$. The detection limits were in the range $0.25-1.0 \mu \mathrm{g} \cdot \mathrm{ml}^{-1}$. The method was applied to the determination of cobalt and iron in pharmaceutical preparations ${ }^{(10)}$.

The use of azo dye, namely 2-mercapto-5-(2,4-dihydroxy-5carboxyphenylazo-1)-1,3,4-tiadiazole (METIDAREZ- $\beta$ ) was proposed for the spectrophotometric determination of Fe(II) in the pharmaceutical multivitamin preparations ${ }^{(11)}$.

In this work a spectrophotometric method has been developed for determination of iron (II) based on chelating reaction with alizarin red sulphonate reagent in neutral aqueous solution and applied successfully in pharmaceutical applications (tablets and capsules).

\section{Apparatus}

\section{EXPERIMENTAL}

A computerized Shimadzu UV-1650 a digital double beam spectrophotometer with $1-\mathrm{cm}$ matched quartz cells was used for all spectral and absorbance measurements.

\section{Reagents}

All chemicals used were of the highest purity available.

Alizarin red sulphonate (ARS) $1 \times 10^{-3} \mathrm{M}$ solution:

This solution was prepared by dissolving $0.0856 \mathrm{~g}$ of ARS in absolute ethanol in $250 \mathrm{ml}$ volumetric flask. This solution was kept in brown bottle and it was stable for at least one month.

Ferrous sulphate solution $\left(1000 \mu \mathrm{g} \cdot \mathrm{ml}^{-1}\right)$

This solution was prepared by dissolving $0.4964 \mathrm{gm}$ of $\mathrm{FeSO}_{4} \cdot 7 \mathrm{H}_{2} \mathrm{O}$ in $100 \mathrm{ml}$ boiling distilled water (this solution was standardized by titration with $0.01 \mathrm{~N}$ potassium permanganate in acidic medium).From this solution $100 \mu \mathrm{g} \cdot \mathrm{ml}^{-1}$ was prepared by dilution with distilled water ${ }^{(12)}$.

\section{Procedure for calibration}

To a series of $10 \mathrm{ml}$ calibrated flasks, transfer an increasing volumes of $100 \mu \mathrm{g} \cdot \mathrm{ml}^{-1}$ of iron (II) solution to cover the concentration 
range $(0.5-5) \mu \mathrm{g} . \mathrm{ml}^{-1}$, followed by addition of $2.5 \mathrm{ml}$ of $1 \times 10^{-3} \mathrm{M} \mathrm{ARS}$, the solution then diluted to the mark with distilled water and absorbance measured at $566 \mathrm{~nm}$ after 20 minutes at room temperature against the reagent blank.

\section{Analysis of tablets}

Ten tablets weighed accurately (each tablet contains $200 \mathrm{mg}$ dried ferrous sulphate which is equivalent to $64 \mathrm{mg}$ elemental iron) crushed, mixed well then a weight equivalent to one tablet was dissolved in $100 \mathrm{ml}$ distilled water, $0.5 \mathrm{gm}$ of charcoal was added, the solution was heated for 10 minutes for colour removal then the solution was filtered and the filtrate was transferred to $500 \mathrm{ml}$ volumetric flask and completed to the mark with distilled water to obtain $128 \mu \mathrm{g}$. $\mathrm{ml}^{-1}$. From this solution 100 $\mu \mathrm{g} . \mathrm{ml}^{-1}$ was prepared by dilution and followed the procedure for calibration to determine iron (II) in tablets.

\section{Analysis of capsules}

Ten capsules were weighed accurately (each capsule contains $150 \mathrm{mg}$ dried ferrous sulphate equivalent to $47 \mathrm{mg}$ elemental iron), weight equivalent to one capsule was dissolved in $100 \mathrm{ml}$ boiled distilled water, $0.5 \mathrm{gm}$ of charcoal was added, the solution was heated for 10 minutes for colour removal then filtered and the filtrate was transferred to $250 \mathrm{ml}$ volumetric flask and completed to the mark with distilled water to obtain $188 \mu \mathrm{g}$. $\mathrm{ml}^{-1}$. From this solution $100 \mu \mathrm{g}$. $\mathrm{ml}^{-1}$ solution was prepared by dilution and followed the procedure for calibration to determine iron (II) in capsules.

\section{Preliminary investigation}

\section{Results and discussion}

When a solution of iron (II) and alizarin red sulphonate reagent were mixed in a neutral aqueous solution a brown solution was observed with maximum absorption at $566 \mathrm{~nm}$ in contrast to the reagent blank which shows a maximum absorption at $420 \mathrm{~nm}$ Figure (1).

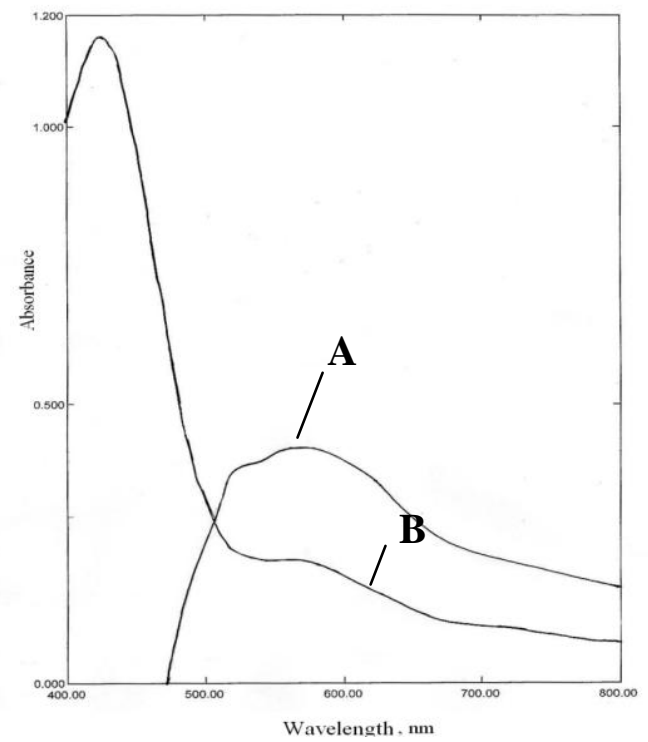

Figure (1):Absorption spectra of A-3 $\mu \mathrm{g} \cdot \mathrm{ml}^{-1}$ iron (II) $-\mathrm{ARS}\left(1 \times 10^{-3} \mathrm{M}\right)$ product versus reagent blank and $B$-Reagent blank versus distilled water 


\section{Optimization of conditions}

Since ARS behaves as an acid base indicator so neither acid nor base could be used in the reaction medium ${ }^{(13)}$.

\section{Effect of temperature and reaction time}

The reaction time was determined by the colour development at room temperature and in thermostatically controlled water-bath adjusted at 40 and $50{ }^{\circ} \mathrm{C}$. The absorbance was measured at 10 minutes intervals against reagent blank. It was observed that the absorbance was reached maximum after 20 minutes at room temperature (RT) and remains constant more than 2 hrs. RT and reaction time $20 \mathrm{~min}$ were chosen for colour development (Table 1).

Table (1): Effect of temperature and reaction time

\begin{tabular}{|c|c|c|c|c|c|c|c|c|c|c|}
\hline \multirow{2}{*}{$\begin{array}{c}\text { Temp. } \\
\left({ }^{\circ} \mathrm{C}\right)\end{array}$} & \multicolumn{10}{|c|}{ Time (min) } \\
\cline { 2 - 12 } & 10 & 20 & 30 & 40 & 50 & 60 & 90 & 100 & 120 & 150 \\
\hline 0 & 0.289 & 0.291 & 0.300 & 0.295 & 0.311 & 0.310 & 0.292 & 0.298 & 0.298 & 0.295 \\
\hline RT & 0.292 & 0.334 & 0.334 & 0.334 & 0.334 & 0.334 & 0.334 & 0.332 & 0.333 & 0.315 \\
\hline 40 & 0.291 & 0.311 & 0.310 & 0.309 & 0.309 & 0.310 & 0.308 & 0.308 & 0.307 & 0.307 \\
\hline 50 & 0.290 & 0.298 & 0.297 & 0.298 & 0.298 & 0.298 & 0.296 & 0.294 & 0.295 & 0.294 \\
\hline
\end{tabular}

\section{Effect of ARS concentration}

The effect of different ARS concentrations on the absorbance of solution containing $3 \mu \mathrm{g}$. ml ${ }^{-1}$ iron (II) was studied, it is evident that the absorbance increases with increasing ARS concentration and reached maximum on using $2.5 \mathrm{ml}$ of $1 \times 10^{-3} \mathrm{M}$ ARS. Therefore, this concentration was used in all subsequent work (Table 2).

Table (2): Effect of ARS concentration

\begin{tabular}{|c|c|c|c|c|c|}
\hline ARS solution $1 \times 10^{-3} \mathrm{M}(\mathrm{ml})$ & 1.5 & 2 & 2.5 & 3 & 3.5 \\
\hline Absorbance & 0.281 & 0.334 & 0.420 & 0.366 & 0.332 \\
\hline
\end{tabular}

\section{Effect of surfactant}

The effect of different types of surfactants were used for the improvement of the absorption intensity, but none of them improve the absorption intensity therefore they were excluded from this study (Table 3). 
Table (3): Effect of surfactant

\begin{tabular}{|c|c|c|c|c|}
\hline \multirow{2}{*}{ Surfactant } & \multicolumn{4}{|c|}{ Absorbance/ml } \\
\cline { 2 - 5 } & 0.5 & 1 & 2 & 3 \\
\hline Cetyltrimethyl ammonium bromide $(0.1 \%)$ & 0.417 & 0.415 & $\begin{array}{c}0.41 \\
5\end{array}$ & 0.413 \\
\hline Sodium dodecyl sulphate (0.1\%) & 0.418 & 0.416 & $\begin{array}{c}0.41 \\
7\end{array}$ & 0.412 \\
\hline Triton x-100 (1\%) & 0.417 & 0.413 & $\begin{array}{c}0.41 \\
5\end{array}$ & 0.413 \\
\hline Without surfactant & \multicolumn{5}{|c|}{0.420} \\
\hline
\end{tabular}

\section{Calibration graph}

Under the optimum conditions, a linear relationship between the absorbance and the concentration of iron (II) was observed cover the concentration range $(0.5-5) \mu \mathrm{g} . \mathrm{ml}^{-1}$ (Fig.2) with correlation coefficient of 0.9998. A negative deviation from Beer's law was observed at higher concentrations of iron (II). The molar absorptivity was $7.8 \times 10^{3}$ 1. $\mathrm{mol}^{-1} \cdot \mathrm{cm}^{-1}$.

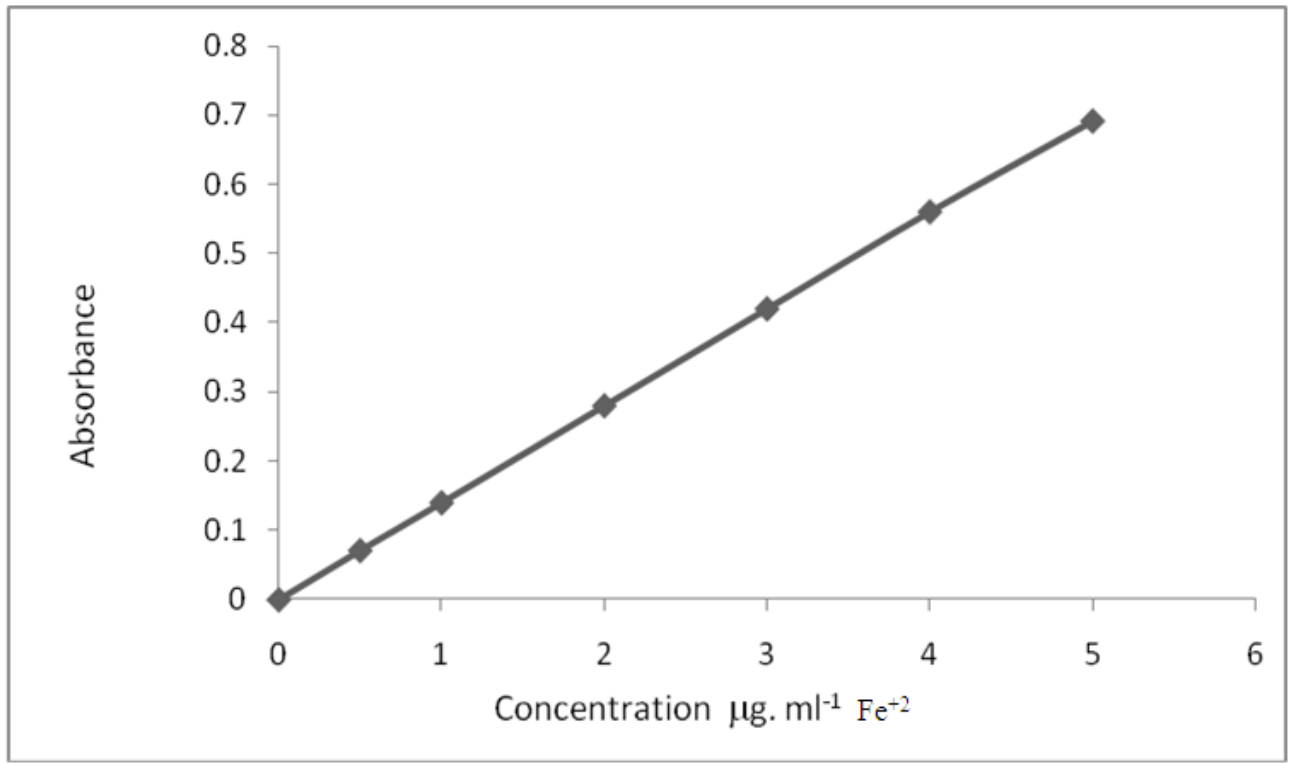

Figure (2): Calibration graph of iron (II)

\section{Accuracy and precision}

To determine the accuracy and precision of the method, iron (II) was determined at three different concentrations. The results in table (4), showed that the accuracy (average recovery\%) was $100.06 \%$ and the precision $(\mathrm{RSD})<1 \%$. 
Thabit S. Al-Ghabsha \& Amal M. Saeed \& Usra I. Al-Neaimy

Table (4): Accuracy and precision of the present proposed method

\begin{tabular}{|c|c|c|}
\hline $\begin{array}{c}\text { Amount of iron (II) taken } \\
\mu \mathrm{g} . \mathrm{ml}^{-1}\end{array}$ & Recovery*\% & $\begin{array}{c}\text { Relative standard } \\
\text { deviation* (RSD\%) }\end{array}$ \\
\hline 2 & 100.36 & 0.94 \\
\hline 3 & 99.76 & 0.56 \\
\hline 4 & 100.06 & 0.54 \\
\hline
\end{tabular}

* Average for six determinations

\section{Effect of interferences}

To check the selectivity of the method, $3 \mu \mathrm{g}$. $\mathrm{ml}^{-1}$ of iron (II) was determined using the recommended procedure in presence of foreign compounds usually present in pharmaceutical formulations. The results didnt show any interfering effect on the present method which indicate that the method is selective (Table 5).

Table (5): Effect of interferences

\begin{tabular}{|c|c|c|}
\hline Foreign compounds & Fold excess & Recovery \% \\
\hline \multirow{2}{*}{$\mathrm{ZnSO}_{4} .7 \mathrm{H}_{2} \mathrm{O}$} & 10 & 100.0 \\
& 20 & 101.5 \\
& 30 & 102.2 \\
\hline \multirow{2}{*}{ Folic acid } & 10 & 101.1 \\
& 15 & 102.0 \\
& 30 & 102.3 \\
\hline \multirow{2}{*}{ Glucose } & 10 & 100.0 \\
& 20 & 99.9 \\
\hline \multirow{3}{*}{ Starch } & 50 & 97.6 \\
& 10 & 98.5 \\
& 15 & 98.6 \\
\hline \multirow{2}{*}{ Glycerol } & 20 & 98.7 \\
& 10 & 100.0 \\
& 20 & 101.2 \\
& 30 & 101.5 \\
\hline \multirow{2}{*}{ Acacia } & 10 & 101.1 \\
& 20 & 101.6 \\
& 50 & 102.0 \\
\hline \multirow{2}{*}{ lactose } & 10 & 101.2 \\
& 15 & 101.7 \\
\hline
\end{tabular}

\section{Nature of product and reaction mechanism}

The stochiometry of the reaction between iron(II) and ARS was investigated using Job's method ${ }^{(14)}$. The results obtained show that 1:2 iron (II): ARS ratio was formed (Fig.3). 


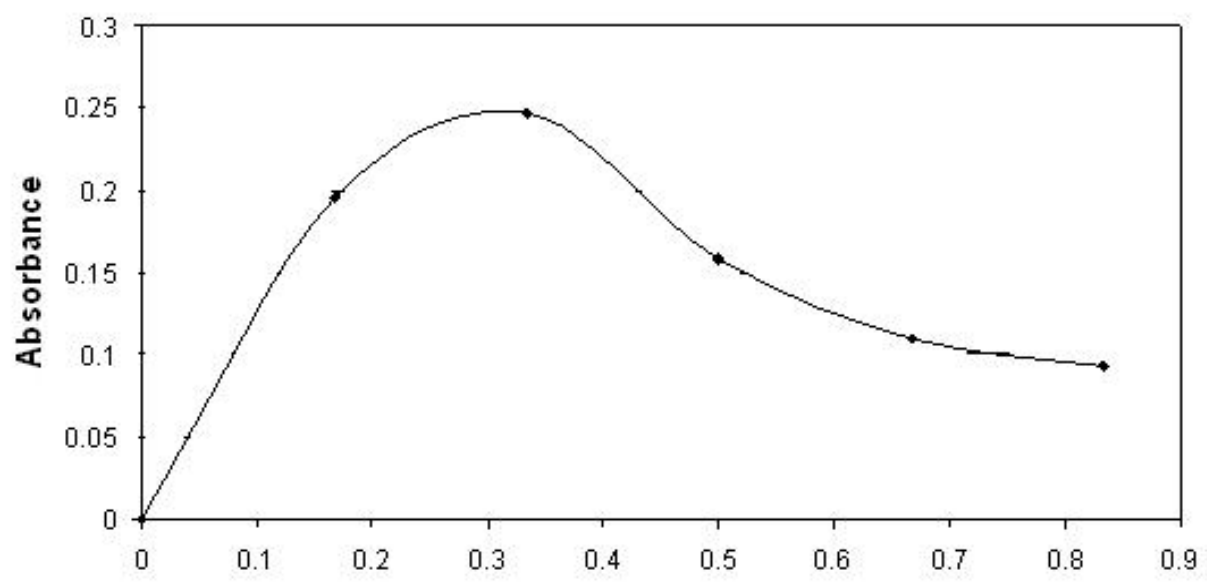

$\left[\mathrm{Fe}^{2+}\right] /\left[\mathrm{Fe}^{2+}\right]+[$ ARS $]$

Figure (3): Job's method for iron (II)-ARS product

Therefore, the formation of the product may be occur as follows<smiles>NS(=O)(=O)c1cc2c(c(O)c1O)C(=O)c1ccccc1C2=O</smiles><smiles>COc1c(C)cc2c(c1OC)C(=O)c1ccccc1C2=O</smiles>

The stability constant of the product was estimated and found to be $4.25 \times 10^{10} 1^{2} . \mathrm{mol}^{-2}$.

\section{Analytical applications}

Five types of pharmaceutical formulations containing iron (II) have been analyzed and they gave a good accuracy (Table 6). The proposed method was compared successfully with British pharmacopoeia standard method $^{(15)}$ (Table 7), since the T-test at three degree of freedom and 95\% confidence limit showed that there was no significant differences between the proposed method and the standard method.

$$
\text { (t-exp. }=0.33, \quad \mathrm{t} \text {-tabulated }=3.18 \text { ). }
$$

Table (6): Application of the proposed method for determination of iron (II) in pharmaceutical formulations

\begin{tabular}{|c|c|c|c|c|c|}
\hline $\begin{array}{c}\text { Pharmaceutical preparation of } \\
\text { and company }\end{array}$ & $\begin{array}{c}\text { Wt of } \\
\text { tablet } \\
(\mathrm{mg})\end{array}$ & $\begin{array}{c}\text { Certified } \\
\text { value of } \\
\text { iron (II) } \\
(\mathrm{mg})\end{array}$ & $\begin{array}{c}\text { Amount of } \\
\text { iron (II) } \\
\text { present } \\
\left(\mu \mathrm{g} \cdot \mathrm{ml}^{-1}\right)\end{array}$ & $\begin{array}{c}\text { Recovery* } \\
\%\end{array}$ & $\begin{array}{c}\text { Drug } \\
\text { content } \\
\text { found (mg) }\end{array}$ \\
\hline $\begin{array}{c}\text { Ferrous sulphate tablets } \\
\text { Ajanta pharma limited, India }\end{array}$ & 200 & 64 & 2 & 100.71 & 64.45 \\
& & 3 & 99.29 & 63.55 \\
1 & & 4 & 100.36 & 64.23 \\
\hline
\end{tabular}


Thabit S. Al-Ghabsha \& Amal M. Saeed \& Usra I. Al-Neaimy

\begin{tabular}{|c|c|c|c|c|c|}
\hline Ferrous sulphate folic acid tablets & 200 & 65 & 2 & 100.35 & 65.22 \\
Holden medical BV, Lelystad. & & & 3 & 100.95 & 65.62 \\
Netherlands & & & 4 & 99.46 & 64.65 \\
\hline Ferrous sulphate folic acid & 150 & 47 & 2 & 99.28 & 46.66 \\
capsules & & & 3 & 99.05 & 46.55 \\
EIPCO / EGYPT & & & 4 & 100.54 & 47.25 \\
\hline Folicron & 650 & 47 & 2 & 98.57 & 46.33 \\
Folic acid + iron & & & 3 & 99.28 & 46.66 \\
Julphar, Gulf pharmaceutical & & & 4 & 100.18 & 47.08 \\
industrial, Ras Al Khaimah, & & & & & \\
U.A.E & 650 & 47 & 2 & 100.71 & 47.33 \\
FEFOL-Z & & 3 & 99.52 & 46.77 \\
Ferrous sulphate, folic acid and & & 4 & 99.82 & 46.92 \\
zinc sulphate & & & & \\
Manufactured by Avenzor & & & & \\
S.A.R & & & & \\
Licenced by Glaxosmithkline, & & & & \\
U.K & & & & \\
\hline
\end{tabular}

\section{Table (7): Comparison of the proposed method with standard method for the determination of iron (II) in pharmaceutical} formulations

\begin{tabular}{|c|c|c|c|c|}
\hline \multirow{2}{*}{$\begin{array}{c}\text { Iron (II) } \\
\text { pharmaceutical } \\
\text { formulation }\end{array}$} & \multicolumn{2}{|c|}{ Present method } & \multicolumn{2}{|c|}{ British pharmacopoeia } \\
\hline & Recovery* \% & $\begin{array}{l}\text { Drug content } \\
\text { found } \mathrm{mg}\end{array}$ & Recovery* \% & $\begin{array}{l}\text { Drug content } \\
\text { found } \mathrm{mg}\end{array}$ \\
\hline \multirow{3}{*}{$\begin{array}{l}\text { Ferrous sulphate } \\
\text { tablets }\end{array}$} & 100.71 & 64.45 & 99.86 & 63.91 \\
\hline & 99.29 & 63.55 & 100.45 & 64.29 \\
\hline & 100.36 & 64.23 & 99.91 & 63.94 \\
\hline \multirow{3}{*}{$\begin{array}{l}\text { Ferrous sulphate } \\
\text { folic acid tablets }\end{array}$} & 100.35 & 65.22 & 100.51 & 65.33 \\
\hline & 100.95 & 65.62 & 99.97 & 64.98 \\
\hline & 99.46 & 64.65 & 99.86 & 64.91 \\
\hline \multirow{3}{*}{$\begin{array}{c}\text { Ferrous sulphate } \\
\text { folic acid } \\
\text { capsules }\end{array}$} & 99.28 & 46.66 & 100.97 & 47.46 \\
\hline & 99.05 & 46.55 & 99.91 & 46.96 \\
\hline & 100.54 & 47.25 & 99.87 & 46.8 \\
\hline \multirow{3}{*}{ Folicron } & 98.57 & 46.33 & 99.12 & 46.62 \\
\hline & 99.28 & 46.66 & 100.23 & 47.10 \\
\hline & 100.18 & 47.08 & 100.68 & 47.32 \\
\hline \multirow{3}{*}{ FEFOL-Z } & 100.71 & 47.33 & 99.95 & 46.98 \\
\hline & 99.52 & 46.77 & 100.14 & 47.07 \\
\hline & 99.82 & 46.92 & 100.25 & 47.12 \\
\hline
\end{tabular}

*Average of six determinations

\section{Comparison of methods}

The results obtained by application of the present method and literature method to the determination of iron (II) in pharmaceutical preparations were given in table (8). 
Spectrophotometric Assay of Iron (II) in Pharmaceutical Formulation Using ...

Table (8): Comparison of methods

\begin{tabular}{|c|c|c|}
\hline Analytical parameter & Present method & Literature method $^{(4)}$ \\
\hline$\lambda_{\max }(\mathrm{nm})$ & 566 & 475 \\
\hline Temp $\left({ }^{\circ} \mathrm{C}\right)$ & R.T & R.T \\
\hline $\mathrm{pH}$ & - & 2.92 (phthalate buffer) \\
\hline Development time (min) & 20 & 5.0 \\
\hline Period time (min) & 120 & 180 \\
\hline Molar absorptivity $1 . \mathrm{mol}^{-1} \cdot \mathrm{cm}^{-1}$ & 7800 & 7550 \\
\hline Linear range $\left(\mu \mathrm{g} . \mathrm{ml}^{-1}\right)$ & $0.5-5$ & $0.05-6.0$ \\
\hline Average recovery $(\%)$ & 100.06 & 99.87 \\
\hline $\operatorname{RSD}(\%)$ & $<1$ & $<1$ \\
\hline Analytical application & Tablets, Capsules & Tablets \\
\hline
\end{tabular}

It is evident from the table that the results compared favorably between the two methods in all analytical parameters but the present method does not require buffer solution.

\section{Conclusion}

The reported method is simple and sensitive. The product formed is stable for at least 120 min., thus permitting quantitative analysis to be carried with good reproducibility, also the reported method does not require neither buffer solution nor solvent extraction.

\section{References}

1) Seiler H.G., Sigel A. and Sigel H., "Handbook of Metals in Clinical and Analytical Chemistry", Marcel Dekker, New York, (1994).

2) Martins F.G., Andrade J.F., Pimenta A.C., Lourenco L.M., Castro J.R.M. and Balb V.R, Eclet. Quim., 30,3,(2005).

3) Al-Jabri F.M. and AL-Salih T.H., Basrah J. Science, 11,19, (1993).

4) Al-Neaimy U.I.S., Ph.D. Thesis, University of Mosul, (2006).

5) Chacaroili C.J., Andrade J.F., Guimaraes O.M., Balbo V.R., Venezuela C.S. and Teruel F.S., Anal Chim. Acta, 411,217, (2000).

6) Tesfaldet Z.O., Staden J.F.V. and Stefan R.I., Talanta, 64,1189, (2004).

7) Zareba S. and Zareba-Giezek M.M,.., Annales, Vol. LIX (7),67, (2004).

8) Karpinska J. and Kulikowska M.,J. Pharm. Biomedical Anal., 29, $153,(2002)$.

9) Khuhawar M. Y. and Lanjwani S. N., Talanta, 46, 485, (1998).

10) Khuhawar M. Y. and Lanjwani S. N., J. Chromatography A, 695(1), 132,(1995).

11) Zareba S. and Szarwilo K, IL Farmaco, 45,3, (2000).

12) Vogel A.I., "A Text-book of Quantitative Inorganic Analysis", $3^{\text {rd }}$ Edn., Longmans, Green and Co. Ltd, London, p.278, (1961).

13) Barbosa, J.; Bosch E. and Carrera, R. Talanta,(1985), 32,1077-1081, Chem. Abst., 104,101425p, (1985).

14) Delevie R., "Principle of Quantitative Chemical Analysis", McGrawHill International Edition, Singapore, p.498, (1997).

15) "British pharmacopoeia", Vol., II, HM Stationary Office, London, p.771, (1980). 